\title{
TRANSLATION METHODS IN LITERARY WORK: A DESCRIPTIVE ANALYSIS OF INDONESIAN'S TRANSLATOR
}

\author{
Harry Prastyo \\ IAI Uluwiyah Mojokerto \\ harrylinguist6@gmail.com
}

\begin{abstract}
Translation is an activity to transfer a message from certain language to other language as similar as the original message from the source text. One of the novel that has good quality in translation is the the Old Man and the Sea (TOMatS) by Ernest Hemingway and it is translated by Dian Vita Elliyati. This research is aimed to investigating the methods used in translating expression of emotion and the frequency of method used in translating them. The last one is to investigate the pattern of translations methods in TOMatS Novel. This research uses descriptive design. The instrument of this research is the writer itself. The data source of this research is the novel entitled The Old Man and the Sea and its translation. Furthermore, the data of this research is all the expression of emotions in the novel The Old Man and the Sea and its translation. The result of this research is that the novel has 55 expression of emotions in TOMatS novel. Meanwhile, from 55 data, the writer found that the translator uses different methods in translating the expression of emotion. The writer found that the translator use literal translation in translating 15 data $(27.27 \%)$, Semantic Translation Method is used to translate 18 data $(32.72 \%)$, Communicative Translation Method is used to translate 18 data too $(32.72 \%)$ and Word-for-Word Translation Method is only used to translate 4 data $(7.27 \%)$. Furthermore, Literal Translation Method is mostly used to translate Emotion of Satisfactory Affection (8 data or 14.55\%). Then Semantic Translation Method is mostly used to translate Emotion of Unsatisfactory Affection (6 data or 10.91\%). In addition, Communicative Translation Method is mostly used to translate Emotion Of Satisfactory Affection (6 data or 10.91\%) and Emotion of Unsatisfactory Affection (6 data or $10.91 \%)$. Additionally, Word-for-Word Translation Method is mostly used to translate Emotion Of Unsatisfactory Affection (2 data or $3.64 \%$ ). For the next researchers who concern to the translation, it is suggested that they investigate the technique used in translating novel because it is very important to help translators, especially for the translators who translate the literary work.
\end{abstract}

Keywords: Translation Method; Expression of Emotions; the Old Manand the Sea; Dian Vita Elliyati. 


\begin{abstract}
Abstrak
Menerjemahkan adalah aktifitas untuk melakukan transfer pesan dari suatu Bahasa ke Bahasa lainnya. Salah satu novel yang memiliki kualitas yang bagus hasil terjemahannya adalah The Old Man and the Sea (TOMaTs) karangan Ernest Hemingway yang diterjemahkan oleh Dian Vita Eliyanti. Penelitian ini bertujuan untuk melakukan investigasi terhadap metode yang digunakan dalam menerjemahkan ekspresi emosi, keberulangan metode terjemahannya, dan pola dalam menerjemahkan. Model deskriptif dilakukan dalam penelitian ini dimana peneliti sebagai instrument penelitiannya, dan datda diperoleh dari novel berjudul The Old Man and the Sea dan terjemahannya. Data dalam penelitian ini berupa ekspresi emosi yang muncul ddalam novel tersebut.

Hasil penelitian ini menunjukkan bahwa novel tersebut memiliki 55 ekspresi emsi, dan penerjemah melakukan metode yang berbeda dalam menerjemahkan novel tersebut. Penerjemah menggunakan 15 data atau sebanyak $22.27 \%$ dengan metode literal translation, masing-masing 18 data atau 32,72\% menggunakan semantic translation method dan Communicative Translation Methjod, dan sebanyak 4 data atau sejumlah 14,55\% menggunakan Word-for-Word Translation Method. Dalam metode penerjemahan literal, penerjemah dominan menggunakan emotion of satisfactory affection, sementara dalam Semantic Translation Method penerjemah dominan menggunakan Emotion of Unsatisfactory Affection. Selanjutnya dalam menerjemahkan menggunakan metode komunikatif, penerjemah lebih dominan menggunakan Emotion of Satisfactory Affection. Untuk metode Word-for-word translation penerjemah dominan menggunakan emotion of unsatisfactory affection. Sehingga disarankan bagi peneliti lainnya yang juga tertarik untuk melakukan penelitia senada, disarankan untuk lebih menggali informasi tentang Teknik yang digunakan dalam melakukan penerjemahan novel, hal ini sangat bermanfaat bagi para penerjemah dalam menerjemahkan karya sastra.
\end{abstract}

Kata Kunci: metode penerjemahan, ekspresi emosi, Novel the Old Man and the Sea, dan Dian Vita Elliyati.

\title{
INTRODUCTION
}

Since translation is considered as an independent studies by Holmes (in Roswita, 2009:10 from Munday), it nowadays becomes research object in term of process, product or science ${ }^{1}$. Translation as a product is a research area that is

\footnotetext{
${ }^{1}$ Jeremy Munday, Introducing Translation Studies: Theories and Applications, 3rd Editions (London and New York: Routledge, 2013), hlm. 10, https://books.google.co.id/books?id=BS8xAAAAQBAJ\&pg=PT375\&dq=Munday,+J.+2001.+Introduci ng+Translation+Studies:+Theories+and+Applications\&hl=en\&sa=X\&ved=0ahUKEwium_fLoeDfAh XFvI8KHdHqCEEQ6AEIKDAA\#v=onepage\&q=Munday\%2C\%20J.\%202001.\%20Introducing\%20Tr anslation $\% 20$ Studies $\% 3 \mathrm{~A} \% 20$ Theories $\% 20$ and $\% 20$ Applications\&f=false.
} 
observed by many researchers because it is often read by the target readers and also it is tangible data which are easy to be accessed to uncover the phenomena in translation activity. There are many definitions about translation. One of them was proposed by Finlay " a translation may be defined as a presentation of a text in a language other than that in which it was originally written". In other words, translation is representation of a text by using different language from the source language. Furthuremore, Larson (in Simatupang) explained that translating is to change a form to other forms ${ }^{3}$. Newmark ${ }^{4}$ also defined the translation meaning as follows "rendering the meaning of a text into another language in the way that the author intended the text". In this case, translation is an activity to tranfer a message from certain language to other languages as similar as the original message from the source text.

Research in translation developed more because at that time it gave beneficial both academically and financially. Academically, translation activity contributed many new sciences, knowledges and informations from some books that were translated. We realize that Indonesia was developing country so it needed many informations about science. At the same time, the science were dominated by books that were written in English. Consequently, the books needed translating. Financially, translation activity also gave beneficial because it was an activity that were needed by some publishers and even individuals. This condition gave contribution financially for the translators.

In translating a text, a translator has some choices that relate to process and principle $^{5}$. In a literary work, both for performance on the stage such as dramatical, and written literary works such as novel, short story and poem, all of them have emotions element and they can reinforce the situation in the story. By having good emotions element, the literary work - such as dramatical, novel, short story or poem - will also have good story because they can make audience or readers to be influenced by the plot of the story and they will not be bored to see or read the story. Consequenltly, translating on emotions element has very

2 Ian F dan Finlay, Teach Yourself Translating (London: The English University Press Limited, 1971), hlm. 1.

${ }^{3}$ Maurits D.S. Simatupang, Pengantar Teori Terjemahan (Jakarta: Depdiknas, 2000), hlm. 1.

${ }^{4}$ Peter Newmark, A Textbook of Translation (New York: Prentice-Hall International, 1988), hlm. 5 .

${ }^{5}$ FX Nadar, Paham dan Terampil Menerjemahkan (Yogyakarta: Fakultas Ilmu Bahasa UGM, 2007), hlm. 17. 
24 | TAZKIR: Jurnal Penelitian Ilmu-ilmu Sosial dan Keislaman

Vol. 04 No. 1 Juni 2018

important role in translating literary works because the role of emotions element in literary works is very important too. A translator should consider the accuracy in diction and context of translation activity.

Many phenomenal literary works, but the works look like ordinary work when the works are translated. In this case, the translation version is not better than the source language version. In other words, there is a problem with the translation version. However, not all the translation version has problem, but there are some translation versions of novel which have good quality. One of the phenomenal works is Novel with the title The Old Man and The Sea by Ernest Hemingway. In this research, the writer will use TOMatS as the abbreviation of The Old Man and The Sea. It is one of the novel in translation version that has good quality because it has been printed three times during a year (April 2008 to January 2009). It shows that the translation method has good quality. Consequenly, the writer chooses this novel as the subject of the research.

Due to the fact that the translation version of the novel is good, the writer would like to observe the method that is used. In this case, the translation method that is used in translating emotions. The role of emotion in literary works is very important because it can reinforce the situation in the story. Furtheremore, it is very important to pay attention to the diction of translating emotion in the novel of The Old Man and The Sea with the translation version because the diction in translating emotion can involve the situation (context) of the target language. Based on this reason, the writer argues that it is very important to do research in term of translating emotions.

One of the phenomenal works is Novel with the title The Old Man and The Sea by Ernest Hemingway. In this research, the writer will use TOMatS as the abbreviation of The Old Man and The Sea. He also will use this novel as the object of this research.

\section{REVIEW OF RELATED THEORIES}

\section{Translation Method}

The method of translation is a global choice that influences the whole text. Basically, translator will determine the method first then the translator translates 
by using some techniques. Newmark ${ }^{6}$ introduces a diagram that he called as $\mathrm{V}$ diagram to show different two poles from the different method of translation.

$\begin{array}{lc}\text { SL Emphasis } & \text { TL Emphasis } \\ \text { Word-for-word } & \text { Adaptation Translation } \\ \text { Literal translation } & \text { Free translation } \\ \text { Faithful translation } & \text { Idiomatic translation } \\ \text { Semantic translation } & \text { Communicative translation }\end{array}$

Diagram 1 : V Diagram of translation method

Translation method that has source language oriented will represent the method of translation: word-for-word translation, Literal translation, Faithful translation and Semantic translation. The following is the discussion:

\section{a. Word-for-word translation}

Word-for-word translation relates to the words. In applying this method, translator looks for the equivalent between source language and target language nd this process does not relate to the context of the words. The translator also does not change the structure of the source language. It means that the structure of source language is the same as the structure of target language. Consequently, translator can use this method if only the structure of source language is the same as the structure of target language.

\section{b. Literal translation}

Literal translation has similarity with word-for-word translation, similarity here mean both literal translation and word-for-word translation get rid of the context. The difference between literal translation and word-for-word translation is literal translation changes the grammatical construction of source language to be the grammatical construction of target language. The following is the example of literal translation.

\section{c. Faithful translation}

Faithful translation attempts to produce contextual meaning of text of source language although it contempt the grammatical structure of target language. The following is the example of faithful translation.

\footnotetext{
${ }^{6}$ Newmark, A Textbook of Translation, hlm. 45.
} 
26 | TAZKIR: Jurnal Penelitian Ilmu-ilmu Sosial dan Keislaman

Vol. 04 No. 1 Juni 2018

\section{d. Semantic translation}

Semantic translation focuses on looking for the equivalent of word with the bound of language of source language culture and attempts to divert contextual meaning of source language as close as possible with syntactic and semantic structure of target language. For instance, if a command sentence in English is translated into Bahasa Indonesia, the sentence in Bahasa Indonesia should be in the form of command sentence too. The words that construct command in English should have the same meaning component with the words that construct command in the target language..

Translation method that has target language oriented will represent the method of translation: Adaptation translation, free translation, Idiomatic translation and Communicative translation. The following is the discussion:

a. Adaptation Translation

Adaptation Translation attempts to change the culture of source language to the culture of source language. The product of this translation does not consider as translation but as product of rewriting message from source language to target language.

The translation product of this method is free translation and it is usually used to translate drama script and poem.

\section{b. Free translation}

Free translation method produces target text that does not have style or form of source text. This method is not bound on rule to find the equivalent of words or sentences. Translator tends to find the equivalent of text. This method is different with adaptation method. Message of target language in free translation should be the same as the message of source language. In this case, translator has freedom to express the message of the source language to target language but does not have freedom to modify the original text. On the contrary, in adaptation method, translator can modify the original text based on the culture of the target language, such as modification of name and place.

\section{c. Idiomatic translation}

Idiomatic translation attempts to reproduce the nmessage of source text but breaks the meaning because of the usage of colloquial or idiom 
although both of them do not exist in the source language. The following is the example of idiomatic translation.

\section{d. Communicative translation}

Communicative translation also considers the effectiveness of language in translation. Consequently, in communicative translation, language in translation should have form, meaning and function because it is possible that a sentence is true based on sintactic point of view but the meaning of the sentence is not logic, or form and meaning are true but the function is wrong.

\section{RESEARCH METHOD}

This research uses descriptive design. According to Ary, Jacobs and Razavich (1985:222) descriptive studies are designed to obtain the current status of phenomena and are directed toward the nature of situation as it exist at the time of the study. Thus the aim of descriptive research is to describe what exist. The data source of this research is the novel entitled The Old Man and the Sea and its translation. The original novel was written by Ernest Hemingway. This novel was published in www.Asiaing.com. The novel was translated by Dian Vita Elliyati on 2009. It was published by Selasar Surabaya Publishing. This translation version was printed out three times by the publisher. ISBN of the translation version is 979259351-9. Furthermore, the data of this research is all the expression of emotions in the novel The Old Man and the Sea and its translation. The researcher was the main instrument in this research to select the data about the emotions in the novel The Old Man and The Sea. The researcher tried to find the equivalent words in the translation novel of The Old Man and the Sea by Dian Vita Elliyati. He used listing method to find the the equivalent words by using dictionary. After getting the expression of emotions both in the source language and target language (by the translator), the researcher tried to classify the methods used in translating emotions, after that the writer analyzed the procentage of the methods used in translating emotions. The code used for translation methods by the researcher is that LT for Literal Translation, ST for Semantic Translation, CT for Communicative Translation and WT for Word-forWord Translation. 
28 | TAZKIR: Jurnal Penelitian Ilmu-ilmu Sosial dan Keislaman

Vol. 04 No. 1 Juni 2018

The following is the steps used in collecting the data:

1. reading novel of source language and reading the novel of target language (translation product by Dian Vita Elliyati);

2. collecting the data by finding words that show emotions both in original novel and translation product;

3. checking the original data with the translation product data;

4. Finding the tarnslation methods by comparing the source language and the traget language in TOMatS Novel.

After finding the data of emotion categories and the translation methods, the writer analyzed the data

1. Classifying the methods used in translating emotions based on V diagram of Newmark; and

2. Making the tabulation of methods used in translating emotions.

\section{FINDINGS AND DISCUSSION}

\section{Findings}

This sub topic provides the data of Translation Methods in translating emotions in TOMatS Novel. In this finding, the writer, found 4 methods used in translating emotions in TOMatS Novel.

\section{Method of Translating Emotion in TOMatS Novel}

In this sub topic, the writer would like to discuss about the method used in translating expression of emotion in TOMatS novel. There 55 data that the writer found in this novel. The writer described 20 data from 55 data. The following is the result:

Datum 1

\begin{tabular}{|l|l|}
\hline $\begin{array}{l}\text { Source } \\
\text { Language }\end{array}$ & $\begin{array}{l}\text { The old man looked at him with his sun-burned, confident } \\
\text { loving eyes. }\end{array}$ \\
\hline $\begin{array}{l}\text { Target } \\
\text { Language }\end{array}$ & $\begin{array}{l}\text { Lelaki tua itu memandanginya dengan bola matanya } \\
\text { yang terbakar matahari menyiratkan hati yang penuh } \\
\text { perasaan sayang dan percaya diri. }\end{array}$ \\
\hline Method & Literal Translation \\
\hline
\end{tabular}

Based on the translated version, we can see that there is a change in grammatical structure of the expression, the phrase the old man is translated with lelaki tua. It 
also happens in the phrase sun-burned, confident loving eyes. Consequently, the writer classifies this expression is translated by using literal translation method.

Datum 2:

\begin{tabular}{|l|l|}
\hline Source & "The Yankees cannot lose." \\
Language & "But I fear the Indians of Cleveland." \\
\hline Target & "Yankess tidak mungkin kalah." \\
Language & "Tapi aku mengkhawatirkan Indians dari Cleveland." \\
\hline Method & Semantic Translation \\
\hline
\end{tabular}

Based on the translated version, we can see that the translator uses the word tidak mungkin for translating cannot and the word mengkhawatirkan for translating fear. It shows that the translator tries to change the semantic meaning of the source language to the target language. Furthermore, the translator also changes the syntactic structure in translating the word cannot. Qonsequently, in this case the translation method used is semanctic translation method.

Datum 7

\begin{tabular}{|l|l|}
\hline $\begin{array}{l}\text { Source } \\
\text { language }\end{array}$ & "I've been asking you to," the boy told him gently. \\
\hline $\begin{array}{l}\text { Target } \\
\text { Language }\end{array}$ & $\begin{array}{l}\text { "Tadi aku sudah mempersilahkan bapak,"si bocah } \\
\text { menjawab sopan. }\end{array}$ \\
\hline Method & Communicative Translation \\
\hline
\end{tabular}

Based on the translated version, the translator uses the word tadi... in translating "I've been asking you to," the boy told him gently. It means that the translator considers the function of the expression.

Datum 8

\begin{tabular}{|l|l|}
\hline $\begin{array}{l}\text { Source } \\
\text { language }\end{array}$ & "I wanted to take him fishing but I was too timid to ask him. \\
\hline $\begin{array}{l}\text { Target } \\
\text { Language }\end{array}$ & $\begin{array}{l}\text { "Aku ingin mengajaknya memancing tapi aku terlalu } \\
\text { malu untuk memintanya. }\end{array}$ \\
\hline Method & Word-for-word translation \\
\hline
\end{tabular}

Based on the translated version, we can see that the translator translates word-by-word from the source language, I wanted to take him fishing but I was too timid to ask him, to the target language, Aku ingin mengajaknya memancing tapi aku terlalu malu untuk memintanya. There is no a change both in syntactic and semantic stucture. 
30 | TAZKIR: Jurnal Penelitian Ilmu-ilmu Sosial dan Keislaman

Vol. 04 No. 1 Juni 2018

Datum 9

\begin{tabular}{|l|l|}
\hline $\begin{array}{l}\text { Source } \\
\text { language }\end{array}$ & Then I asked you to ask him and you were too timid." \\
\hline $\begin{array}{l}\text { Target } \\
\text { Language }\end{array}$ & $\begin{array}{l}\text { Lalu aku memintamu untuk mengajaknya dan kau juga } \\
\text { segan." }\end{array}$ \\
\hline Method & Word-for-word translation \\
\hline
\end{tabular}

Based on the translated version, we can see that the translator translates word-by-word from the source language, Then I asked you to ask him and you were too timid, to the target language, Lalu aku memintamu untuk mengajaknya dan kau juga segan. There is no a change both in syntactic and semantic stucture.

Datum 10

\begin{tabular}{|l|l|}
\hline Source & $\begin{array}{l}\text { "He used to come to the Terrace sometimes too in the older } \\
\text { language } \\
\text { he wat he was rough and harsh-spoken and difficult when }\end{array}$ \\
\hline $\begin{array}{l}\text { Target } \\
\text { Language }\end{array}$ & $\begin{array}{l}\text { "Sesekali ia bisa datang ke Beranda pada masa lalu. } \\
\text { Tetapi sikapnya kasar, sering berkata keras, dan jadi } \\
\text { menyulitkan ketika mabuk. }\end{array}$ \\
\hline Method & Communicative translation \\
\hline
\end{tabular}

Based on the translated version, the translator uses the word sesekali... in translating "He used to come to the Terrace sometimes too in.... It means that the translator considers the meaning of the expression for the readers of target language.

Datum 18

\begin{tabular}{|l|l|}
\hline $\begin{array}{l}\text { Source } \\
\text { language }\end{array}$ & $\begin{array}{l}\text { He was very fond of flying fish as they were his principal friends } \\
\text { on the ocean. }\end{array}$ \\
\hline $\begin{array}{l}\text { Target } \\
\text { Language }\end{array}$ & $\begin{array}{l}\text { Ia sangat menyukai ikan terbang seperti sahabat sejatinya } \\
\text { di laut. }\end{array}$ \\
\hline Method & Semantic translation \\
\hline
\end{tabular}

Based on the translated version, the translator uses context of target language in translating ... as they were his principal friends on the ocean to be ... seperti sahabat sejatinya di laut. She does not translate they were. It 
shows that the translator tries to change the semantic meaning of the source language to the target language.

Datum 20

\begin{tabular}{|l|l|}
\hline Source & $\begin{array}{l}\text { Why did they make birds so delicate and fine as those sea } \\
\text { swallows when the ocean can be so cruel? She is kind and very } \\
\text { beautiful. }\end{array}$ \\
\hline $\begin{array}{l}\text { Target } \\
\text { Language }\end{array}$ & $\begin{array}{l}\text { Mengapa mereka menciptakan burung-burung begitu } \\
\text { halus dan rapuh seperti burung layang-layang laut } \\
\text { sedangkan lautan begitu kejamnya? Dia ramah dan sangat } \\
\text { cantik. }\end{array}$ \\
\hline Method & Communicative translation \\
\hline
\end{tabular}

Based on the translated version, the translator uses the words ...rapuh in translating fine. It means that the translator considers the meaning of the expression for the readers of target language.

Datum 21

\begin{tabular}{|l|l|}
\hline $\begin{array}{l}\text { Source } \\
\text { language }\end{array}$ & $\begin{array}{l}\text { He always thought of the sea as la mar which is what people } \\
\text { call her in Spanish when they love her. }\end{array}$ \\
\hline $\begin{array}{l}\text { Target } \\
\text { Language }\end{array}$ & $\begin{array}{l}\text { Ia selalu berpikir lautan sebagai la mar, sebutan yang } \\
\text { digunakan di Spanyol karena mereka mencintainya. }\end{array}$ \\
\hline Method & Semantic translation \\
\hline
\end{tabular}

Based on the translated version, the translator uses context in translating ... when to be ...karena. It shows that the translator tries to change the semantic meaning of the source language to the target language.

Datum 22

\begin{tabular}{|l|l|}
\hline $\begin{array}{l}\text { Source } \\
\text { language }\end{array}$ & he was happy to see so much plankton because it meant fish. \\
\hline $\begin{array}{l}\text { Target } \\
\text { Language }\end{array}$ & $\begin{array}{l}\text { Ia senang mengetahui banyaknya plankton karena itu } \\
\text { berarti ada banyak ikan. }\end{array}$ \\
\hline Method & Communicative translation \\
\hline
\end{tabular}

Based on the translated version, the translator uses the words itu berarti ada banyak ikan in translating it meant fish. It means that the translator considers the meaning of the expression for the readers of target language.

Datum 23

\begin{tabular}{|l|l|}
\hline Source & "Agua mala," the man said. "You whore." \\
\hline
\end{tabular}


32 | TAZKIR: Jurnal Penelitian Ilmu-ilmu Sosial dan Keislaman

Vol. 04 No. 1 Juni 2018

\begin{tabular}{|l|l|}
\hline language & \\
\hline $\begin{array}{l}\text { Target } \\
\text { Language }\end{array}$ & "Agua mala, " kutuk lelaki tua. "Pelacur kau." \\
\hline Method & Semantic translation \\
\hline
\end{tabular}

Based on the translated version, the translator uses context in translating ... the man said to be kutuk lelaki tua. It shows that the translator tries to change the syntactic and semantic meaning of the source language to the target language.

Datum 25

\begin{tabular}{|l|l|}
\hline $\begin{array}{l}\text { Source } \\
\text { language }\end{array}$ & $\begin{array}{l}\text { He loved green turtles and hawk-bills with their elegance and } \\
\text { speed and their great value }\end{array}$ \\
\hline $\begin{array}{l}\text { Target } \\
\text { Language }\end{array}$ & $\begin{array}{l}\text { Dia menyukai penyu hijau dan paruh elang karena } \\
\text { bentuknya yang elegan dan kecepatannya juga nilainya } \\
\text { yang tinggi. }\end{array}$ \\
\hline Method & Literal translation \\
\hline
\end{tabular}

Based on the translated version, we can see that there is a change in grammatical structure of the expression, the phrase green turtle is translated with penyu hijau. It also happens in hawk-bills and great value which is translated with paruh elang and nilainya yang tinggi.

Datum 27

\begin{tabular}{|l|l|}
\hline $\begin{array}{l}\text { Source } \\
\text { language }\end{array}$ & $\begin{array}{l}\text { "Albacore," he said aloud. "He'll make beautiful bait. He'll } \\
\text { weigh ten pounds." }\end{array}$ \\
\hline $\begin{array}{l}\text { Target } \\
\text { Language }\end{array}$ & $\begin{array}{l}\text { "Albacore," teriaknya. "Dia akan menjadi umpan yang } \\
\text { cantik. Beratnya sepuluh ton." }\end{array}$ \\
\hline Method & Literal translation \\
\hline
\end{tabular}

Based on the translated version, we can see that there is a change in grammatical structure of the expression, the phrase beautiful bait is translated with umpan yang cantik.

Datum 28

\begin{tabular}{|l|l|}
\hline $\begin{array}{l}\text { Source } \\
\text { language }\end{array}$ & \begin{tabular}{l} 
Then he felt the gentle touch on the line and he was happy. \\
\hline $\begin{array}{l}\text { Target } \\
\text { Language }\end{array}$
\end{tabular} \\
$\begin{array}{l}\text { Berikutnya ia merasakan sentuhan lembut pada talinya } \\
\text { dan ini membuatnya senang. }\end{array}$ \\
\hline
\end{tabular}




\begin{tabular}{|l|l|}
\hline & \\
\hline Method & Literal translation \\
\hline
\end{tabular}

Based on the translated version, we can see that there is a change in grammatical structure of the expression, the phrase gentle touch is translated with sentuhan lembut.

Datum 29

\begin{tabular}{|l|l|}
\hline $\begin{array}{l}\text { Source } \\
\text { language }\end{array}$ & $\begin{array}{l}\text { He was happy feeling the gentle pulling and then he felt } \\
\text { something hard and unbelievably heavy. }\end{array}$ \\
\hline $\begin{array}{l}\text { Target } \\
\text { Language }\end{array}$ & $\begin{array}{l}\text { Ia merasa senang merasakan tarikan lembut dan } \\
\text { kemudian merasakan sesuatu yang keras dan luar biasa } \\
\text { berat. }\end{array}$ \\
\hline Method & Literal translation \\
\hline
\end{tabular}

Based on the translated version, we can see that there is a change in grammatical structure of the expression, the phrase gentle pulling is translated with tarikan lembut. It also happens in something hard which is translated with sesuatu yang keras.

Datum 30

\begin{tabular}{|l|l|}
\hline $\begin{array}{l}\text { Source } \\
\text { language }\end{array}$ & "I wish I had the boy" the old man said aloud. \\
\hline $\begin{array}{l}\text { Target } \\
\text { Language }\end{array}$ & $\begin{array}{l}\text { "Andai si bocah bersamaku," lelaki tua itu berharap } \\
\text { dengan berteriak kencang. }\end{array}$ \\
\hline Method & Communicative translation \\
\hline
\end{tabular}

Based on the translated version, the translator uses the words Andai si bocah bersamaku in translating I wish I had the boy and the words said aloud in translating said aloud. It means that the translator considers the meaning of the expression for the readers of target language.

Datum 31

\begin{tabular}{|l|l|}
\hline $\begin{array}{l}\text { Source } \\
\text { language }\end{array}$ & Then he began to pity the great fish that he had hooked. \\
\hline $\begin{array}{l}\text { Target } \\
\text { Language }\end{array}$ & $\begin{array}{l}\text { Selanjutnya ia merasa kasihan terhadap ikan besar yang ia } \\
\text { telah ia kail. }\end{array}$ \\
\hline Method & Communicative translation \\
\hline
\end{tabular}


34 | TAZKIR: Jurnal Penelitian Ilmu-ilmu Sosial dan Keislaman

Vol. 04 No. 1 Juni 2018

Based on the translated version, the translator uses the word selanjutnya in translating then and the word terhadap as addition in the middle of the expression. It means that the translator considers the meaning of the expression for the readers of target language.

Datum 35

\begin{tabular}{|l|l|}
\hline $\begin{array}{l}\text { Source } \\
\text { language }\end{array}$ & $\begin{array}{l}\text { The boy was sad too and we begged her pardon and } \\
\text { butchered her promptly. }\end{array}$ \\
\hline $\begin{array}{l}\text { Target } \\
\text { Language }\end{array}$ & $\begin{array}{l}\text { Si bocah juga merasa sedih dan kami memohon } \\
\text { ampunnya dan mencincangnya dengan hormat. }\end{array}$ \\
\hline Method & Literal translation \\
\hline
\end{tabular}

Based on the translated version, we can see that there is a change in grammatical structure of the expression, the phrase sad too is translated with juga....sedih.

Datum 36

\begin{tabular}{|l|l|}
\hline $\begin{array}{l}\text { Source } \\
\text { language }\end{array}$ & $\begin{array}{l}\text { There was yellow weed on the line but the old man knew } \\
\text { that only made an added drag and he was pleased. }\end{array}$ \\
\hline $\begin{array}{l}\text { Target } \\
\text { Language }\end{array}$ & $\begin{array}{l}\text { Nampak rumput laut berwarna kuning pada tali pancing } \\
\text { tetapi lelaki tua itu tahu bahwa itu hanya akan menambah } \\
\text { beban tarikan dan itu membuatnya senang. }\end{array}$ \\
\hline Method & communicative Translation \\
\hline
\end{tabular}

Based on the translated version, the translator uses the word tali pancing in translating line. It means that the translator considers the meaning of the expression for the readers of target language.

Datum 42

\begin{tabular}{|l|l|}
\hline $\begin{array}{l}\text { Source } \\
\text { language }\end{array}$ & I wonder why he jumped, the old man thought. \\
\hline $\begin{array}{l}\text { Target } \\
\text { Language }\end{array}$ & Aku bayangkan bagaimana ia melompat, pikirnya. \\
\hline Method & Literal translation \\
\hline
\end{tabular}

Based on the translated version, we can see that there is a change in grammatical structure of the expression, the phrase the old man thought is translated with pikirnya. In this case, the word_nya refers to the old man again.

Datum 43 


\begin{tabular}{|l|l|}
\hline $\begin{array}{l}\text { Source } \\
\text { language }\end{array}$ & $\begin{array}{l}\text { He was comfortable but suffering, although he did not admit } \\
\text { the suffering at all. }\end{array}$ \\
\hline $\begin{array}{l}\text { Target } \\
\text { Language }\end{array}$ & $\begin{array}{l}\text { Ia merasa nyaman sekaligus menderita, walaupun ia tak } \\
\text { mampu mengakuinya sama sekali. }\end{array}$ \\
\hline Method & Communicative translation \\
\hline
\end{tabular}

Based on the translated version, the translator uses the word sekaligus in translating but and the words tak mampu mengakuinya in translating did not admit. It means that the translator considers the meaning of the expression for the readers of target language.

Datum 44

\begin{tabular}{|l|l|}
\hline $\begin{array}{l}\text { Source } \\
\text { language }\end{array}$ & $\begin{array}{l}\text { "I have never seen or heard of such a fish. But I must kill } \\
\text { him. I am glad we do not have to try to kill the stars." }\end{array}$ \\
\hline $\begin{array}{l}\text { Target } \\
\text { Language }\end{array}$ & $\begin{array}{l}\text { "Aku belum pernah melihat atau mendengar ikan } \\
\text { semacam ini, tetapi aku harus membunuhnya. Aku } \\
\text { senang kita tak harus membunuh bintang-bintang." }\end{array}$ \\
\hline Method & Literal translation \\
\hline
\end{tabular}

Based on the translated version, we can see that there is a change in grammatical structure of the expression, the phrase such a fish is translated with ikan semacam itu.

Datum 47

\begin{tabular}{|l|l|}
\hline $\begin{array}{l}\text { Source } \\
\text { language }\end{array}$ & He is my fortune, he thought. \\
\hline $\begin{array}{l}\text { Target } \\
\text { Language }\end{array}$ & Ia adalah keberuntunganku, pikirnya. \\
\hline Method & Literal translation \\
\hline
\end{tabular}

Based on the translated version, we can see that there is a change in grammatical structure of the expression, the phrase my fortune is translated with keberuntunganku. It also happens in he thought which is translated with pikirnya.

Datum 50

\begin{tabular}{|l|l|}
\hline $\begin{array}{l}\text { Source } \\
\text { language }\end{array}$ & I'm sorry about it, fish. It makes everything wrong." \\
\hline Target & Aku menyesal akan kejadian ini, ikan. Ini membuat \\
\hline
\end{tabular}


36 | TAZKIR: Jurnal Penelitian Ilmu-ilmu Sosial dan Keislaman

Vol. 04 No. 1 Juni 2018

\begin{tabular}{|l|l|}
\hline Language & segalanya menjadi salah." \\
\hline Method & Semantic translation \\
\hline
\end{tabular}

Based on the translated version, the translator uses context in translating I'm sorry about it to be Aku menyesal akan kejadian ini. It shows that the translator tries to change the semantic meaning of the source language to the target language.

\section{Tabulation of Translation Methods of Emotion in TOMatS Novel}

In this sub-topic, the writer would like to tabulate the data found based on method used in translating emotion. The following is the result:

Table 4.2: Translation Methods used in translating Expression of Emotions

\begin{tabular}{|c|c|c|c|c|}
\hline $\begin{array}{l}\mathbf{N} \\
\mathbf{0}\end{array}$ & Method & Datum number & Amount & Percentage \\
\hline 1 & $\begin{array}{l}\text { Literal } \\
\text { translation }\end{array}$ & $\begin{array}{l}1,11,25,27,28,29,34,35 \\
, 38,39,40,42,44,47,51 .\end{array}$ & 15 data & $27.3 \%$ \\
\hline 2 & $\begin{array}{l}\text { Semantic } \\
\text { translation }\end{array}$ & $\begin{array}{l}2,3,4,5,6,13,15,16,18,1 \\
9,21,23,24,26,41,48,50 \\
, 53\end{array}$ & 18 data & $32.7 \%$ \\
\hline 3 & $\begin{array}{l}\text { Communicativ } \\
\text { e translation }\end{array}$ & $\begin{array}{l}7,10,12,17,20,22,30,31 \\
, 32, \\
, 33,36,37,43,45,46,49 \\
52,54\end{array}$ & 18 data & $32.7 \%$ \\
\hline 4 & Word-for-word & $8,9,14,55$ & 4 data & $7.3 \%$ \\
\hline \multicolumn{3}{|c|}{ Amount } & 55 data & $100 \%$ \\
\hline
\end{tabular}

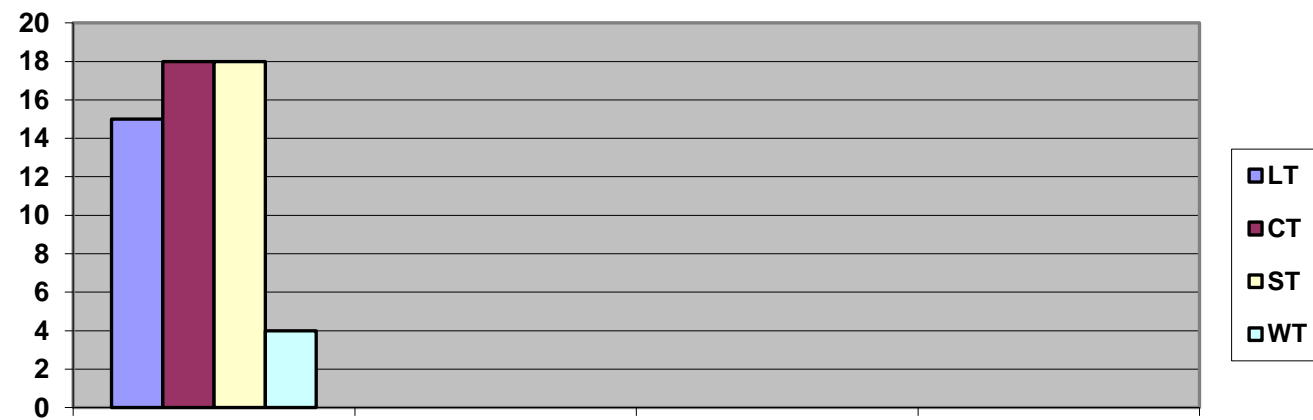

Mark:

LT : Literal Translation

CT : Communicative Translation

ST : Semantic Translation

WT : Word-for-Word Translation 
Based on the data above, the writer found 55 data which are translated by using 4 methods, they are literal translation that has 15 data $(27.3 \%)$, semantic translation that has 18 data $(32.7 \%)$, communicative translation that has 18 data $(32.7 \%)$, and the last is word-for-word translation that has 4 data $(7.3 \%)$. It means that the translator used Semantic and communicative translation method more than other methods.

\section{DISCUSSION}

In discussing translation method used in translating expression of emotions, the writer uses $\mathrm{V}$ diagram proposed by Newmark. According to Newmark $^{7}$ that he he introduces diagram that he called as V diagram to show different two poles from the different method of translation. In this research, after reading the novel as the source language and reading translated version in Bahasa Indonesia as the target language, the writer finds 4 types of method that are used to translate 55 expressions of emotions. They are literal translation, smantic translation, communicative translation and wor-for-word translation. The following is the discussion:

There are 15 data which are translated by using literal translation. They are datum 1 , datum 11 , datum 25 , datum 27 , datum 28 , datum 29 , datum 34 , datum 35 , datum 38 , datum 39 , datum 40 , datum 42 , datum 44 , datum 47 , and datum 51 .

Furthermore, there are 18 data which are translated by using semantic translation method. They are datum 2, datum 3, datum 4, datum 5, datum 6, datum 13 , datum 15 , datum 16 , datum 18 , datum 19 , datum 21 , datum 23 , datum 24, datum 26, datum 41, datum 48, datum 50 and datum 53.

Furthermore, there are 18 data which are translated by using communicative translation method. They are datum 7 , datum 10, datum 12 , datum 17 , datum 20 , datum 22 , datum 30 , datum 31 , datum 32 , datum 33 , datum 36, datum 37, datum 43, datum 45, datum 46, datum 49, datum 52 and datum 54 .

In addition, there are 4 data which are translated by using word-for-word translation method. They are datum 8, datum 9, datum 14, and datum 55.

In short, in this research, the writer found 55 data which are translated by using 4 methods, they are literal translation that has 15 data $(27.27 \%)$, semantic

\footnotetext{
${ }^{7}$ Newmark, hlm. 45.
} 
38 | TAZKIR: Jurnal Penelitian Ilmu-ilmu Sosial dan Keislaman

Vol. 04 No. 1 Juni 2018

translation that has 18 data $(32.72 \%)$, communicative translation that has 18 data $(32.72 \%)$, and the last is word-for-word translation that has 4 data $(7.27 \%)$. Based on the data above about the translation methods used that semantic translation methods are mostly used in translating emotions. It shows that the translator considered the culture of the source language in translating emotions. According to Newmark ${ }^{8}$ that semanctic translation focuses on looking for the equivalent of words with the bound of language of source language culture. Furthermore, communicative translation methods are also mostly used in translating emotions. It means that the translator considered the target language readers. According to Newmark $^{9}$ that communicative translation considers the effectiveness of language in translation (in the target language of the translation).

\section{CONCLUSION AND SUGGESTION}

From 55 data, the writer found that the translator uses different methods in translating the expression of emotion. The writer found that the translator use literal translation in translating 15 data $(27.3 \%)$, semantic translation method is used to translate 18 data $(32.7 \%)$, communicative translation method is used to translate 18 data too (32.7\%) and word-for-word translation method is only used to translate 4 data $(7.3 \%)$. Based on the data found above, we can conclude that it is better for the translators to use semantic and communicative translation method in translating novel instead of using word-for-word translation method.

Furthermore, literal translation method is mostly used to translate emotion of satisfactory affection (8 data or 14.6\%). Then semantic translation method is mostly used to translate emotion of unsatisfactory affection (6 data or $10.9 \%$ ). In addition, communicative translation method is mostly used to translate emotion of satisfactory affection (6 data or 10.9\%) and emotion of unsatisfactory affection (6 data or 10.9\%). Additionally, word-for-word translation method is mostly used to translate emotion of unsatisfactory affection (2 data or 3.6\%). In general, literal translation method is used to translate 16 data (29.1\%), semantic translation is used to translate 18 data $(32.7 \%)$, communicative translation method is used to translate 17 data (30.9\%) and word-for-word translation method is used to translate 4 data $(7.3 \%)$.

\footnotetext{
${ }^{8}$ Newmark, hlm. 45.

${ }^{9}$ Newmark, hlm. 45.
} 
After conducting this research, the writer suggests for the other translators, who want to translate expression of emotion, to use semantic translation method and communicative translation method because both the methods are mostly used in translating expression of emotion in TOMatS novel.

In addition, the writer suggests for the lecturers who teach translation in order to train the students in using semantic translation method and communicative translation method for translating novel.

For the next researchers who concern to the translation, it is suggested that they investigate the technique used in translating novel because it is very important to help translators, especially for the translators who translate the literary work. 
40 | TAZKIR: Jurnal Penelitian Ilmu-ilmu Sosial dan Keislaman

Vol. 04 No. 1 Juni 2018

\section{REFERENCES}

Ian F, dan Finlay. Teach Yourself Translating. London: The English University Press Limited, 1971.

Munday, Jeremy. Introducing Translation Studies: Theories and Applications. 3rd Editions. London and New York: Routledge, 2013. https://books.google.co.id/books?id=BS8xAAAAQBAJ\&pg=PT375\&dq=M unday,+J.+2001.+Introducing+Translation+Studies:+Theories+and+Applica tions\&hl=en\&sa=X\&ved=0ahUKEwium_fLoeDfAhXFvI8KHdHqCEEQ6A EIKDAA\# $\mathrm{v}=$ onepage\&q=Munday $\% 2 \mathrm{C} \% 20 \mathrm{~J} . \% 202001 . \% 20$ Introducing $\% 20$ Translation $\% 20$ Studies $\% 3 \mathrm{~A} \% 20$ Theories $\% 20$ and $\% 20$ Applications\&f=fals.

Nadar, FX. Paham dan Terampil Menerjemahkan. Yogyakarta: Fakultas Ilmu Bahasa UGM, 2007.

Newmark, Peter. A Textbook of Translation. New York: Prentice-Hall International, 1988.

Simatupang, Maurits D.S. Pengantar Teori Terjemahan. Jakarta: Depdiknas, 2000. 